\title{
POTENSI ANTIMIKROBA DARI EKSTRAK DAN FRAKSI SPONS APLYSINA sp. TERHADAP MIKROBA UJI Escherichia coli, Staphylococcus aureus DAN Candida albicans.
}

\author{
Marcelinda Nike Kotel, ${ }^{1)}$ Defny S. Wewengkang, ${ }^{1)}$ Herny. Simbala ${ }^{1)}$ \\ ${ }^{1)}$ Program Studi Farmasi FMIPA UNSRAT Manado, 95115
}

\begin{abstract}
Sponge Aplysina sp. is one of the marine biota, which has bioactive compounds that can be used as medicinal ingredients. This study aims to determine the antimicrobial potential of the extracts and fractions of sponge Aplysina sp., against microbes tested of Escherichia coli, Staphylococcus aureus, and Candida albicans. Aplysina sp., sponge was extracted using maceration method with ethanol solvent and fractionated using methanol, $n$-hexan and chloroform solvents. To test the antimicrobial activity carried out by disk diffusion agar method and observations carried out 24 hours incubation period, with inhibition zones measured using a digital caliper. The results showed that samples of Aplysina sp., proved to have antimicrobial compounds to inhibit Gram-positive bacteria Staphylococcus aureus, and Gram-negative bacteria Escherichia coli, with the highest inhibitory zone activity, and found in Gram -positive Staphylococcus aureus bacteria with measurements of 7,37 $\mathrm{mm}$.
\end{abstract}

Keywords: Sponge Aplysina sp, Antimicrobial, Extraction, Fractionation.

\begin{abstract}
ABSTRAK
Spons Aplysina sp merupakan salah satu biota laut yang memiliki senyawa bioaktif yang dapat dijadikan sebagai bahan obat. Penelitian ini bertujuan untuk mengetahui potensi antimikroba dari Ekstrak dan Fraksi Spons Aplysina sp Terhadap Mikroba Uji Echerichia coli, Staphylococcus aureus, dan Candida albicans. Spons Aplysina sp diekstraksi menggunakan metode maserasi dengan pelarut etanol dan difraksinasi menggunakan pelarut methanol, n-hexan, dan Kloroform. Untuk pengujian aktivitas antimikroba dilakukan dengan metode difusi agar dan pengamatan dilakukan 1x24 jam masa inkubasi, dengan zona hambat diukur menggunakan digital caliper. Hasil penelitian menunjukkan bahwa sampel Spons Aplysina sp terbukti memiliki senyawa antimikroba untuk menghambat bakteri Gram positif Staphylococcus aureus dan bakteri Gram negatif Echerichia coli, dengan aktivitas zona hambat tertinggi, terdapat pada bakteri Gram positif Staphylococcus aureus dengan hasil pengukuran $7,37 \mathrm{~mm}$.
\end{abstract}

Kata Kunci : Spons Aplysina sp, Antimikroba, Ekstraksi, Fraksinasi. 


\section{PENDAHULUAN}

Spons adalah hewan yang hidup menetap pada suatu habitat pasir, batu-batuan atau karang-karang mati didalam laut yang bersifat menyaring makanan. Spons memiliki kemampuan $77 \%$ untuk menyaring bakteri yang ada disekitarnya dengan pemanfaatan makanan yang dicerna secara enzimatik. Ekstrak dari Spons dipercaya memiliki senyawa bioaktif yang mempunyai sifat sitotoksin, anti tumor, antivirus, dan anti inflamasi. Selain memiliki senyawa bioaktif, Spons juga melekat atau menempel pada beberapa benda keras bawah laut seperti karang, dan bebatuan (Haedar,2016). Menurut Wilkinson (1980) Spons Aplysina sp memiliki senyawa bioaktif. Spesies Aplysina adalah penghuni umum perairan laut tropis dan sub tropis dangkal. Seperti Spons pada umumnya Spesies ini memiliki tubuh yang berpori dan permukaan yang keras seperti batu. Spons Aplysina sp merupakan spons besar dengan warna kuning kehijau-an. Beberapa Spons memiliki warna yang berbeda, Spons yang hidup dilingkungan yang gelap warnanya akan berbeda dengan spons yang hidup dilingkungan yang terang. Mikrosimbion pada Spons, umumnya Cyanophita (Cyanobacteria dan Eukariot alga seperti Dinoflagella atau zooxanthella). Fotosintesa mikrosimbion mempengaruhi warna pada Spons.

\section{METODE PENELITIAN}

\section{Alat}

Alat-alat yang digunakan dalam penelitian ini yaitu masker, sarung tangan, gunting, pisau, tabung oksigen, snorkel, fins, zipper lock bag, botol, talenan, cool box, cawan petri, autoklaf, pinset, pembakar spritus, vortex mixer, micro tubes, batang pengaduk, kamera underwater, erlenmeyer, pyrex corong, oven, timbangan analitik, spatula, corong pisah, gelas ukur, gelas kimia (Pyrex), Laminar air flow, rak tabung reaksi, tabung reaksi, lemari pendingin, inkubator, cakram (paper disc), mikropipet, digital caliper, kertas label, spidol permanen.

\section{Bahan}

Bahan-bahan yang digunakan dalam penelitian ini adalah Spons Aplysina sp, mikroba Uji, Escherichia Coli, Staphylococcus aureus, dan Candida albicans, aquades, etanol, metanol, kloroform, n-heksan, kloramfenikol, pepton, beef extract, natrium klorida, agar, paper disc, tissue, aluminium foil, plastic wrap, kertas saring, es batu.

\section{Prosedur Kerja \\ Pengambilan Sampel}

Sampel Spons Aplysina sp diambil dari Selat Lembeh Bitung menggunakan alat bantu (masker snorkel, dan tabung oksigen). Sampel yang didapat dimasukkan ke dalam zipper lock bag selanjutnya diletakkan didalam cool box, kemudian langsung dibawa ke Laboratorium Farmakognosi dan Fitokimia Program Studi Farmasi Universitas Sam Ratulangi. Sampel difoto dan diberi label serta nomor selanjutnya dideterminasi.

\section{Ekstraksi}

Spons Aplysina sp sebanyak 430 g diekstraksi dengan cara maserasi. Sampel dibersihkan kemudian dipotong kecil- kecil dan dimasukan ke dalam botol. Pelarut etanol kemudian ditambahkan sampai sampel terendam semuanya dan dibiarkan selama 24 jam. Sampel yang direndam selama 24 jam selanjutnya disaring menggunakan kertas saring dan menghasilkan filtrat 1 dan Debris 1 . Debris 1 kemudian diremaserasi dengan pelarut 
etanol sampai terendam semuanya dan dibiarkan selama 24 jam, setelah 24 jam, sampel disaring dengan menggunakan kertas saring menghasilkan filtrat 2 dan Debris 2 . perlakuan yang sama dilakukan pada Debris 2,untuk mendapatkan filtrat 3, dan Debris 3. Filtrat 1,2,dan 3 selanjutnya dicampur menjadi satu kemudian disaring dengan kertas saring, lalu dikeringkan menggunakan oven dengan suhu $40^{\circ} \mathrm{C}$. Ekstrak yang didapat dari hasil pengeringan menggunakan oven selanjutnya ditimbang dan didapatlah ekstrak etanol sebanyak 1,36 g yang selanjutnya akan digunakan dalam fraksinasi dan pengujian antimikroba.

\section{Fraksinasi}

Ekstrak kasar spons Aplysina $S p$ sebanyak $1 \mathrm{~g}$ dimasukkan kedalam erlenmeyer, kemudian dilarutkan dengan campuran metanol air (MeOH: $\mathrm{H}_{2} \mathrm{O}$ ) (80 : 20) sebanyak $100 \mathrm{ml}$. Setelah larut, sampel dimasukan kedalam corong pisah dan ditambahkan pelarut nheksan sebanyak $100 \mathrm{ml}$ setelah itu dikocok berulang kali dalam corong pisah sampai homogen. Dibiarkan hingga terbentuk lapisan metanol dan lapisan n-heksan, kemudian masing- masing lapisan yang terbentuk ditampung dalam wadah yang berbeda. Lapisan n-heksan selanjutnya dikeringkan menggunakan oven dengan suhu $40^{\circ} \mathrm{C}$, selanjutnya ditimbang dan diperoleh jumlah ekstrak yang dihasilkan fraksi n- heksan 0,03 g. Selanjutnya lapisan metanol ditambahkan akuades $100 \mathrm{ml}$ kemudian dipartisi dengan pelarut kloroform dengan perbandingan $1: 1 \mathrm{v} / \mathrm{v}$ setelah itu dikocok kembali sampai homogen. Dibiarkan sampai tebentuk dua lapisan yaitu lapisan metanol dan kloroform, dan Masing-masing lapisan tersebut ditampung dalam wadah yang berbeda.Lapisan kloroform selanjutnya dikeringkan menggunakan oven dengan suhu $40^{\circ} \mathrm{C}$, lalu ditimbang dan diperoleh hasil sebanyak 1,6 g fraksi kloroform. Lapisan metanol kemudian dikeringkan menggunakan oven dengan suhu $40^{\circ} \mathrm{C}$ lalu ditimbang dan diperoleh fraksi metanol sebanyak 3,9 g. Hasil dari ketiga fraksi akan digunakan dalam pengujian antimikroba.

\section{Sterilisasi Alat}

Dalam proses penelitian, alat-alat yang akan digunakan harus disterilisasi terlebih dahulu untuk membebaskan semua peralatan dari semua mikroorganisme. Pada pengujian antimikroba alat-alat disterilkan dengan menggunakan autoklaf pada suhu $121^{\circ} \mathrm{C}$ selama 15 Menit, pinset dibakar dengan pembakaran diatas api langsung dan media disterilkan diautoklaf pada suhu $121^{\circ} \mathrm{C}$ selama 15 menit (Mpila, 2012).

\section{Kultur Mikroba}

Mikroba yang digunakan yaitu Escherichia coli dan Staphylococcus aureus. sebanyak 100 $\mu \mathrm{L}$ menggunakan mikropipet Masing-masing mikroba diambil dari biakan murni . kemudian dimasukan kedalam tabung reaksi yang berisi media cair B1 sebanyak $1 \mathrm{ml}$ sebelum di inkubasi dalam incubator dengan suhu $37^{\circ} \mathrm{C}$ selama 1 x 24 jam, tabung reaksi ditutup menggunakan aluminium foil (Ortez, 2005).

\section{Pembuatan Media Uji}

Pepton $0,5 \mathrm{~g}$, beef extract $0,3 \mathrm{~g}$, natrium klorida 0,3 g, agar 1,5 g dan akuades sebanyak $100 \mathrm{ml}$ aduk sampai homogen kemudian sterilkan di autoklaf pada suhu $121^{\circ} \mathrm{C}$ selama 15 menit (Dwijendra et al, 2014).

\section{Pembuatan Larutan Uji}

Dalam $200 \mu \mathrm{L}$ metanol, 1mg ekstrak spons Aplysina sp dilarutkan dan dikocok 
hingga homogeny menggunakan vortex. Perlakuan yang sama di-lakukan pada fraksi nheksan, fraksi kloroform dan fraksi metanol (Ortez, 2005).

\section{Pembuatan Kontrol Positif dan Kontrol Negatif}

Kontrol positif dalam pengujian potensi antimikroba ini meng gunakan kloramfenikol paper disc. Kontrol negatif yang digunakan yaitu pelarut metanol. sebanyak $200 \mu \mathrm{L}$ metanol diambil untuk membuat larutan stok metanol kemudian di totolkan pada paper disc (Lalamentik, 2017).

\section{Pengujian Aktivitas Antimikroba}

Dalam pengujian potensi antimikroba digunakan metode difusi agar (disc diffusion Kirby and Bauer). Mikroba Sebanyak $100 \mu \mathrm{L}$ yang telah dikultur, dipipet dan diinokulasi pada $100 \mathrm{ml}$ media agar lalu diaduk hingga homogen dan kemudian dituangkan ke dalam cawan petri dan tunggu sampai media agar mengeras. masing-masing cakram ditotolkan dengan larutan uji yang telah disiapkan menggunakan mikropipet. Setelah agar mengeras, kertas cakram yang telah ditotolkan sampel spons Aplysina sp, kontrol positif dan kontrol negatif diletakkan ke dalam cawan petri dengan menggunakan pinset. Selanjutnya, cawan petri diberi label dan diinkubasi dalam inkubator pada suhu $37^{0} \mathrm{C}$ selama 1 x 24 Jam (Ortez,2005).

\section{Pengamatan dan Pengukuran Diameter Zona Bening}

Pengamatan dilakukan setelah 24 jam masa inkubasi. Daerah di sekitar kertas cakram yang menunjukkan zona bening kemudian diukur menggunakkan digital caliper dengan cara diukur diameter zona bening horizontal ditambahkan dengan diameter zona bening vertikal lalu dibagi dua. Kemudian zona bening yang telah diukur, Kekuatan daya antimikroba dikategorikan berdasarkan pedoman Davis dan Stout (1971) yaitu $\leq 5$ dikategorikan lemah, 510 dikategorikan sedang ,10-20 dikategorikan kuat, dan $\geq 20$ dikategorikan sangat kuat.

\section{HASIL DAN PEMBAHASAN}

Ekstraksi dan Fraksinasi

Spons Aplysina sp diekstraksi untuk menarik senyawa-senyawa aktif yang terdapat pada Spons. Proses ekstraksi bertujuan untuk memisahkan satu atau dua komponen yang terdapat pada bahan alam dengan bantuan pelarut (Suryanto,2012). Ekstraksi yang dilakukan menggunakan metode maserasi dengan cara perendaman sampel menggunakan pelarut etanol. Pelarut etanol, digunakan karena pelarut ini mampu mengekstrak senyawa secara optimum (Depkes Ri,1986).

Keberhasilan dari ekstraksi dipengaruhi oleh pelarut. Pelarut yang akan digunakan harus memperhatikan faktor selektivitas, kelarutan, dan titik didih. Proses ekstraksi dihentikan ketika tercapai keseimbangan antara kosentrasi senyawa dalam pelarut dengan kosentrasi sel dalam sel tanaman (Mukriani, 2014).

Fraksinasi adalah proses pemisahan dan pengelompokan senyawa-senyawa pada ekstrak berdasarkan tingkat kepolaran (Hawkins and Rahn). Sifat-sifat atau golongan senyawa yang akan dipisahkan merupakan salah satu faktor yang harus diperhatikan dalam menentukan pemilihan metode pemisahan kandungan kimia. Secara selektif masing-masing pelarut akan memisahkan kandungan kimia yang ada. Dalam proses pemisahan menggunakan pelarut polar, non polar, dan semi, polar (Harbone, 1987).

Pelarut yang digunakan dalam melakukan fraksinasi didasarkan pada tingkat kepolaran 
dan dimaksudkan untuk mengelompokan lebih spesifik senyawa yang akan ditarik dari ekstrak etanol.Pelarut yang digunakan dalam penelitian ini diantaranya metanol, n-heksan dan kloroform. Dimana pelarut $\mathrm{MeOH}$ bersifat polar, pelarut heksan bersifat non polar dan kloroform bersifat semi polar. Ekstrak kasar etanol $1 \mathrm{~g}$ dipartisi dengan metanol-air $(\mathrm{MeOH})$, n-hexan, dan kloroform. Dari fraksinasi ini, didapatlah 3 fraksi dengan filtrat yang berbeda yaitu fraksi n-hexan menghasilkan filtrat berwarna orange pekat dengan ekstrak kental yang didapat $0,03 \mathrm{~g}$, fraksi kloroform menghasilkan filtrat berwarna kuning keruh dengan ekstrak kental yang didapat 1,6 g. Fraksi metanol menghasilkan filtrat putih keruh dengan ekstrak kental yang didapat 3,9 g.

Dari metode ekstraksi dan fraksinasi diperoleh hasil rendemen yang disajikan pada Tabel 1.

Tabel 1. Hasil Rendemen Ekstrak dan Fraksi Spons Aplysina sp.

\begin{tabular}{cccc}
\hline No & Sampel & $\begin{array}{c}\text { Rendemen } \\
\%\end{array}$ & Warna Sampel \\
\hline 1 & EKE & 0,3 & Orange Pekat \\
2 & FH & 3 & Orange Pekat \\
3 & FK & 160 & Kuning Keruh \\
4 & FM & 390 & Putih Keruh \\
\hline
\end{tabular}

Dari hasil yang diperoleh pada Tabel 1, menunjukkan adanya perbedaan nilai rendemen. Perbedaan nilai rendemen ini disebabkan oleh penggunaan jenis pelarut yang berbeda, tergantung tingkat kepolarannya. Oleh sebab itu jenis pelarut yang akan digunakan menentukan jumlah ekstrak yang akan dihasilkan. Berdasarkan nilai rendemen yang dihasilkan jumlah nilai rendemen terbesar ditunjukkan pada pelarut fraksi kloroform dan pelarut fraksi metanol. Tingginya nilai rendemen ini disebabkan karena hasil fraksi kloroform dan fraksi metanol yang diperoleh pada saat fraksinasi melebihi nilai ekstrak kasar etanol yang digunakan. Hal ini dikarenakan pelarut kloroform dan metanol yang dikeringkan, tidak menguap secara sempurna sehingga menghasilkan ekstrak kental.

\section{Pengujian Aktivitas Antimikroba}

Pada pengujian aktivitas antimikroba dilakukan dengan metode difusi agar. Menurut Mpila (2012) metode ini mudah dan serbaguna untuk pertumbuhan bakteri yang tumbuh cepat. Selain itu metode difusi agar sering digunakan dalam uji kepekaan antibiotik. Metode ini dilakukan dengan cara melakukan pengamatan dan pengukuran disekitar kertas cakram yang memiliki kepekaan dalam menghambat atau membunuh mikroba yang ditunjukkan dengan adanya zona bening.

Pada pengujian ini, pengamatan dan pengukuran dilakukan 1x 24 jam masa inkubasi pada suhu $37^{\circ} \mathrm{C}$, dengan mikroba uji yang digunakan bakteri Escherichiacoli mewakili bakteri Gram negatif, Staphylococcus aureus mewakili bakteri Gram positif dan Candida albicans mewakili jamur. Mikroba uji ini digunakan untuk mengetahui kemampuan daya hambat dari ekstrak dan fraksi spons Aplysina sp. Pengulangan sebanyak 3 kali dilakukan untuk mendapatkan hasil yang lebih akurat.

Tabel 2. Hasil pengukuran diameter zona hambat Ekstrak dan Fraksi Spons Aplysina sp.

Rata-Rata Diameter Zona Hambat (mm)

\begin{tabular}{ccccccc}
\hline Mikroba & EE & FH & FK & FM & + & \\
\hline E.coli & & & & & & \\
S. & 0,00 & 0,00 & 0,00 & 7,32 & 8,49 & 0,00 \\
aureus & 0,00 & 0,00 & 0,00 & 7,37 & 18,47 & 0,00 \\
Candida & 0,00 & 0,00 & 0,00 & 0,00 & 15,00 & 0,00 \\
albicans & & & & & & \\
\hline
\end{tabular}


Pada pengujian aktivitas antimikroba, kekuatan antimikroba sampel Spons Aplysina sp dikategorikan menurut kategori kekuatan daya antimikroba Davis and Stout (1971) yang disajikan pada Tabel 3 .

Tabel 3. Kategori kekuatan daya antimikroba sampel Spons Aplysina sp.

\begin{tabular}{cc}
\hline Kategori & $\begin{array}{c}\text { Diameter zona bening } \\
(\mathrm{mm})\end{array}$ \\
\hline Sangat Kuat & $\geq 20$ \\
\hline Kuat & $10-20$ \\
\hline Sedang & $5-10$ \\
\hline Lemah & $\leq 5$ \\
\hline
\end{tabular}

Pada ekstrak kasar etanol, fraksi heksan, dan fraksi kloroform, dalam pengujian ini menunjukkan tidak adanya aktivitas antimikroba pada bakteri Escherchia coli, Staphylococcus aureus dan Candida albicans. hal ini menujukkan bahwa ekstrak kasar etanol, fraksi heksan, dan fraksi kloroform tidak memiliki senyawa daya hambat.

Pada fraksi metanol berdasarkan hasil yang diperoleh, bahwa fraksi ini menunjukkan aktivitas antimikroba pada bakteri Escherichia coli, dan bakteri Staphylococcus aureus, namun tidak menunjukkan adanya aktivitas antimikroba pada jamur. Hal ini menunjukkan bahwa fraksi metanol dari Spons Aplysina sp memilki spektrum kerja yang sempit karena hanya mampu mengahambat pertum buhan bakteri dan tidak memiliki aktivitas menghambat jamur. Fraksi metanol pada bakteri Staphylococcus aureus (Gram positif) kekuatan aktivitas zona hambat yang dihasilkan dikategorikan sedang dengan hasil pengukuran yang diperoleh yaitu $(7,37 \mathrm{~mm})$ lebih besar dari pada hasil yang diperoleh pada bakteri Escherichia coli (Gram negatif) yaitu $(7,32 \mathrm{~mm})$ dengan kategori sedang untuk kekuatan zona hambatnya. Hasil ini sesuai dengan penelitian Pelezar dan Chan (1986) dan Fardiaz (1989) yang menyatakan bahwa bakteri Gram negatif memiliki struktur dinding sel yang kompleks, sedangkan bakteri Gram positif memiliki struktur dinding sel yang lebih sederhana.

Dalam pengujian ini kontrol positif yang digunakan yaitu antibiotik kloramfenikol. Dari hasil pengukuran yang diperoleh, menunjukkan bahwa aktivitas zona hambat tertinggi yaitu $(18,49 \mathrm{~mm})$ terdapat pada bakteri Escherichia coli dibandingkan dengan zona hambat yang dihasilkan pada bakteri Staphylococcus aureus yaitu (18, $47 \mathrm{~mm})$. Hal ini disebabkan karena bakteri Gram negatif memiliki kepekaan terhadap kloramfenikol dan hanya membutuh kan 0,2-0,5 $\mu \mathrm{g} / \mathrm{mL}$ kosentrasi, untuk menghambat bakteri sedangkan pada bakteri Gram positif pada umumnya dihambat pada kosentrasi 1-10 $\mu \mathrm{g} / \mathrm{mL}$ (Katzung, 2004). Selain itu Kontrol positif dari kloramfenikol memiliki kemampuan dalam menghambat pertumbuhan Candida albicans dengan hasil pengukuran $(15,00 \mathrm{~mm})$. Hasil ini sesuai dengan peneltian (Katzung, 2004) yang menyatakan bahwa kontrol positif dari antibiotik kloramfenikol memiliki spektrum kerja yang luas sehingga mampu menghambat pertumbuhan bakteri dan jamur .

\section{Kesimpulan}

Berdasarkan hasil penelitian yang dilakukan maka disimpulkan bahwa sampel Spons Aplysina sp, memiliki senyawa antimikroba untuk menghambat bakteri Gram positif Staphylococcus aureus dengan hasil pengukuran $(7,37 \mathrm{~mm})$ dan bakteri Gram negatif Escherichia coli dengan hasil (7,32 $\mathrm{mm})$. Dari hasil pengujian yang dilakukan, diperoleh aktivitas zona hambat tertinggi terdapat pada bakteri Gram positif 
Staphylococcus aureus dengan hasil pengukuran $(7,37 \mathrm{~mm})$.

\section{DAFTAR PUSTAKA}

Davsis, W., Stout., T.R. 1971. Dise Plate Methode of Microbiological Antibiotik Assay , Journal Microbiology. 22 (4) : 659-665.

DeLeo. F.R. Diep, B.A., Otto, M. 2009. Host defense and pathogenesi Staphylococcus aureus infection, Journal Dent, 23:17-34.

Depkes RI.1986. Sediaan Galenik, 2 \& 10. Departemen Kesehatan RI, Jakarta.

Dwijendra, I.M., D.S. Mewengkang, F.S. Wehantow. 2014. Aktivitas Antibakteri dan Karakteristik Senyawa Fraksi Spons Lamellodysidea herbacea yang Diperoleh dari Teluk Manado. Pharmacon Jurnal Ilmiah Farmasi 4:2302- 2493.

Haedar, Baru Sadarun, Ratna Diyah Palupi, 2016. Potensi keanekaragaman Jenis dan Sebaran Spons di Perairan Pulau Saponda Laut, Kabupaten Konawe, Jurnal Sapa Laut Vol. 1 (1):1-9

Harbone,J.B. 1987. Metode Fitokima: Penuntuncara modern menganalisis Terjemahan dari: Phytochemical Methods.

Hawkins, D.W \& D.W. Rahn. 1997. Pharmacotheraphy A. Phatophysiologyc Approach, 3 th Ed. Stampfor: Aplleton and Lange

Katzung, Betram G.2004, Farmakologi Dasar dan Klinik Edisi 4. Alih Bahasa: Staf Dosen Farmakologi Fakultas Kedokteran Universitas Sriwijaya Jakarta; EGC:709-719
Lalamentik, G. J. 2017. Aktivitas Antibakteri Ekstrak Karang Lunak Klyxumsp. Yang diperoleh dari Teluk Manado 6 (3) : 46-56

Mpila,D. A. 2012. Uji Aktivitas Anti bakteri Ekstrak Etanol Daun Mayana aureus dan Escherichia coli dan Pseudumonas aeruginosa secara in vitro [skripsi]. Program Studi Farmasi FMIPA Universitas Sam Ratulangi.

Mukriani,2014.Ekstraksi, Pemisahan Senyawa dan Identifikasi Senyawa Aktif jurnal Kesehatan Kesehatan Vol. 7 . No 2. Hal: 361-367

Ortez, J. H. 2005. Disk Diffusion testing inmanual of antimicrobial susceptibility testinMarie B. Coyle(Coord. Ed). American society for Microbiology dan America.

Pelezar, M.J., Chan, E. C.S. 1986. Dasar-dasar Mikrobiologi 2 Hadioetomo R. S.,Imas,T., Tijtrosomo dan angka $s, L$. Jakarta

Suryanto, E. 2012. Fitokimia Antioksidan. Putra Media Nusantara, Surabaya. Soest R. Van, 2008. World Porifera Database. [di akses 14 Oktober 2018]

Wilkinson, C.R.1980. Cyanobacteria symbiotik in marine sponges. In SCHWEMMLER et al (Eds). Endo cytobiology : endosymbiosis and cell 